\title{
A portrait of central Italy's geology through Giotto's paintings and its possible cultural implications
}

\author{
Ann C. Pizzorusso \\ independent researcher: 511 Avenue of the Americas, New York, New York 10011, USA
}

Correspondence: Ann C. Pizzorusso (tweetingdavinci@gmail.com)

Received: 26 February 2020 - Discussion started: 14 April 2020

Revised: 6 October 2020 - Accepted: 26 October 2020 - Published: 15 December 2020

Abstract. Central Italy has some of the most complex geology in the world. In the midst of this inscrutable territory, two people emerged - St. Francis and Giotto - and they would ultimately change the history of ecology, religion and art by extolling the landscapes and geology of this region.

From antiquity to the Middle Ages, humans had a conflicting relationship with nature, seeing it as representing either divine or satanic forces. On the vanguard of a change in perspective toward the natural world was St. Francis of Assisi (ca. 1181-1226) who is now, thanks to his pioneering work, a patron of ecology. He set forth the revolutionary philosophy that the Earth and all living creatures should be respected as creations of the Almighty.

St. Francis' affinity for the environment influenced the artist Giotto (ca. 1270-1337), who revolutionized art history by including natural elements in his religious works. By taking sacred images away from heaven and placing them in an earthly landscape, he separated them definitively from their abstract, unapproachable representation in Byzantine art. Giotto's works are distinctive because they portray daily life as blessed, thus demonstrating that the difference between the sacred and profane is minimal.

Disseminating the new ideas of St. Francis visually was very effective, as the general populace was illiterate. Seeing frescoes reflecting their everyday lives in landscapes that were familiar changed their way of thinking. The trees, plants, animals and rocky landscapes were suddenly perceived as gifts from the Creator to be used, enjoyed and respected. Furthermore, Giotto recognized that the variety of dramatic landscapes would provide spectacular visual interest in the works. By including the striking landforms of central Italy, and portraying them accurately, Giotto allows us the opportunity to identify the types of rock in his frescoes and possibly even the exact locations he depicted. In fact, it would be discoveries in the pink Scaglia Rossa limestone depicted in Giotto's frescoes as pink buildings and used to construct the Basilica of St. Francis at Assisi - which would revolutionize the history of geology.

\section{Introduction}

For a number of years, an international group of scientists and artists have been exploring the many connections between Earth science and art. As a geologist, I have long appreciated an artists' ability to capture the beauty of the Earth in a painting, poem or sculpture. While I can analyze the rock formations and marvel at the mystery of the Earth's topography, it takes an artist to move me to tears by presenting their unique view of the landscape. In doing so, an artist presents the Earth using the visual, a tool so powerful it can move the most naïve viewer to experience the divine nature of the Earth.

My fascination with St. Francis developed because of his revolutionary ideas regarding ecology, but I soon learned that, without the illustration of his ideas in frescoes by Giotto, he might not have had such a powerful and lasting impact. The analysis of Giotto's frescoes from a geological standpoint was a challenge as St. Francis' monasteries were located in central Italy, a region that has some of the most complex and still unexplained geology in the world. Yet, it was precisely this geology that made Giotto's frescoes full of geomorphological wonder. He integrated his figures into this dramatically disordered landscape, forming a compelling composition for any viewer. The scenes portrayed in the frescoes have survived 700 years, allowing modern geologists 
the opportunity to study and compare them to formations visible today. In fact, discoveries in the pink Scaglia Rossa limestone ended up being the key to solving some of the most perplexing questions in historical geology.

In order to appreciate the revolutionary ideas of St. Francis and Giotto, a background on the medieval ideas pertaining to nature will be discussed. A select number of frescoes will be analyzed geologically, with attendant historical information explaining the scene. Geologic maps which can be used as references for the cited locations are also included.

\subsection{The idea of nature in the Middle Ages}

In the Middle Ages, the practice of linking natural phenomena to divine or satanic forces was the norm (Artz, 2014). Since nature's behavior could not be predicted or controlled, medieval people lived in a constant state of awareness of its capriciousness. In order to alleviate stress, a method of spiritual interpretation called anagoge was devised by medieval theologians, notably St. Victor (ca. 1096-1141), to explain natural occurrences. This meant that one had to search for the meaning of God's messages in nature through the complex and oftentimes arbitrary symbolism he chose to use (Cadden, 1995). It was thought that, by deciphering and diffusing malefic symbols, one could avoid disaster or, in the case of auspicious portents, obtain a fortuitous outcome. The search for meaning in nature was much more important than the search for how nature works, as mechanisms were not valued (Chenu, 1983). After all, God was in charge of everything and what he was doing behind the scenes did not matter. As a result, people tried to become more empathetic and more closely aligned to nature to understand God.

\subsection{St. Francis}

In the early 1200s, a young man from Assisi named Giovanni di Pietro di Bernardone, but known to us as Francis, gained a following for his revolutionary ideas pertaining to a sympathetic view of nature. Francis lived in Umbria, a region of Italy which is green, fertile and infused with a palpable spirituality. He was born into a well-to-do family of cloth merchants. As a young man, he renounced his own material wealth, even taking the position that the Church do the same. He walked to towns and villages, espousing a simple way of life and encouraging a reverential attitude toward the natural world for he believed that nature was the mirror of God. He called all creatures his brothers and sisters and preached that people had a duty to protect and enjoy nature as the stewards of God's creation (French and Cunningham, 1996). He constructed a series of monasteries (Fusarelli, 1999) which were situated in forests or snuggled up against the sides of mountains (Fig. 1). His own cell and bed were carved out of rock. Francis was also a poet and an outstanding innovator in the history of Italian literature. In his Canticle of the Sun, be-

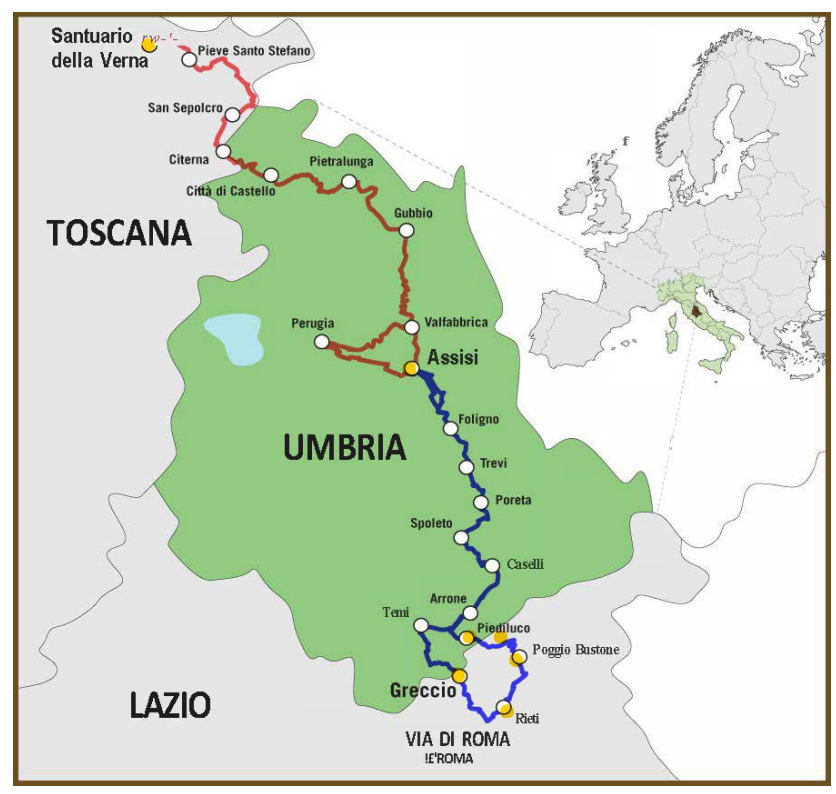

Figure 1. Map showing selected Franciscan monasteries in Tuscany, Lazio and Umbria (in yellow) and walking paths from one to another. Note that there are others in Italy which were not chosen as part of this study. Source: public domain - Wiki Commons.

lieved to be the first work written in the Italian language, he praised God for creating "Brother Sun" and "Sister Moon".

Soon he attracted a group of followers which were organized into many religious orders for both men and women (Nessi, 1991). He became so influential that the Pope had to acknowledge him and allow his orders (Order of Friars Minor, the women's Order of Saint Clare, the Third Order of Saint Francis and the Custody of the Holy Land) to be officially recognized by the Church.

Francis was so venerated that Pope Gregory IX canonized him in 1228 , only two years after his death, and ordered a basilica be constructed in Assisi. It was built with indigenous pink Scaglia Rossa limestone (Fig. 2) and completed in 1253. Astonishingly, this Scaglia Rossa limestone, depicted in Giotto's frescoes, held the key which would revolutionize the history of geology.

\subsection{Giotto}

The Pope ordered scenes of the life of St. Francis to decorate the interior of the basilica. It was covered with frescoes painted by several generations of Italian artists. Among the many famous names who worked in the Assisi basilica were Cimabue (1240-1302), Duccio (ca. 1255-1319) and Giotto (1267-1337). They sought to honor St. Francis by portraying his life in a series of frescoes which not only served a proselytizing function but also changed the history of art. This one building became the most fruitful single training school and meeting place in the history of Western art (Moleta, 1983). 


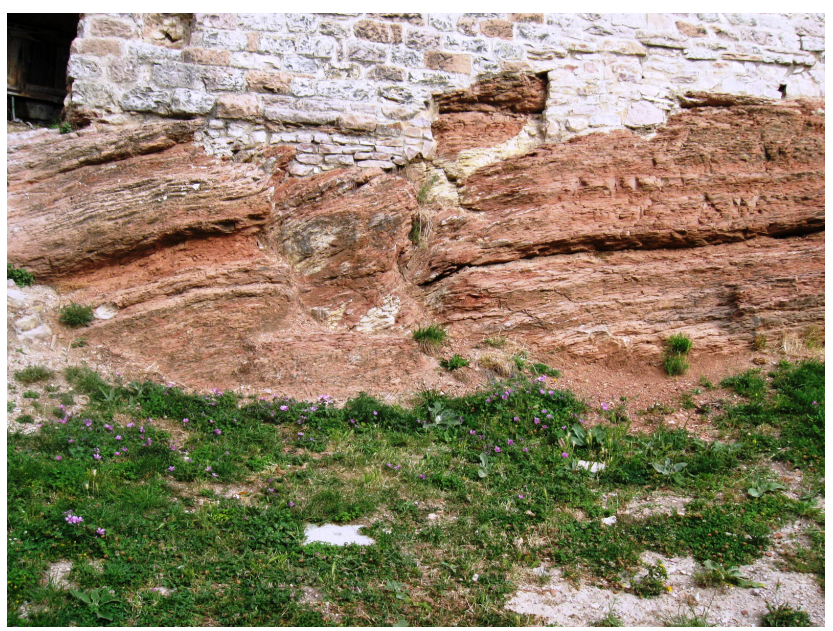

Figure 2. Pink streaked with white Scaglia Rossa limestone is a pelagic sedimentary rock with forams and clay in a coccolith matrix dating from the Late Cretaceous to Middle Eocene. It was mined from the Mt. Subasio quarry and used to construct the St. Francis basilica at Assisi. Source: public domain - Wiki Commons.

Giotto's works were so revolutionary that today he is considered the founder of Renaissance art (Moleta, 1983). But the seeds of this dramatic stylistic transformation were planted by Cimabue, who worked at Assisi during the pontificate (1288-1292) of Nicholas IV, the first Franciscan pope. Cimabue broke from the rigidness of Byzantine art, where figures were rendered flat and one-dimensional (Dall'Asta, 2012). Instead, he made them more realistic by using proportions and shading for volume.

Giotto followed Cimabue's lead in changing the flat figures of the Byzantine art form, conducive to contemplation, to a more relaxed style by showing people in a natural setting (Dall'Asta, 2012). He observed the landscape and sought to portray its beauty and order. He used painting techniques to depict figures more solidly so that they would appear 3D and, thus, created the illusion that they were moving through a landscape within the picture. Giotto integrated sacred images into the earthly landscape, separating them definitively from their abstract representation in Byzantine art. By portraying daily life, the realm of the sacred appears to be diminished, but that of the profane acquires a grand dignity and seriousness, which became Giotto's distinctive characteristic.

Additionally, both Duccio (a contemporary of Giotto's) and Giotto were among the first to add a depth perspective to their paintings. This was revolutionary as the rules of perspective had been lost in the Dark Ages (Blatt, 1984). Duccio used modeling (playing with light and dark colors) to reveal the physique beneath the clothing's heavy drapery. Hands, faces and feet became more rounded and 3D, giving his figures vitality. Giotto used various techniques, such as presenting his buildings obliquely to take up more space in depth, and presenting his figures with volume, scale and perspec-

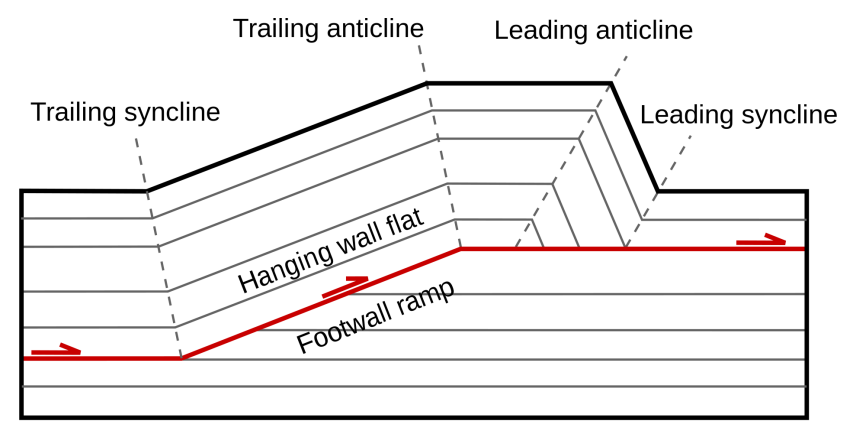

Fault-bend fold

Figure 3. Diagram of the anticlinal fold mountains formed by compression. Source: public domain - Wiki Commons.

tive to evoke realism (Edgerton, 1993, 1975). The two artists also placed their figures within natural settings, paying special attention to plants, trees, and animals, and making detailed rock formations an integral part of the scene. As a result, their figures interacted with one another, creating a sense of fluidity and movement in a realistic landscape, which was astounding to the medieval viewer.

The inclusion of natural elements in visual art as a method of disseminating the new ideas of St. Francis was very effective, as the general populace was illiterate. Seeing frescoes reflecting their everyday lives in familiar landscapes changed their way of thinking (Panofsky, 1997). The trees, plants, animals and rocky landforms which had never been valued suddenly became part of the incredible universe that God had created (Crombie, 1996). The Earth, and all things living upon its glorious terrain, were gifts from the Creator to be used, enjoyed and respected. Duccio and Giotto used nature as a symbol, as the stage on which the mystery of life, both spiritual and temporal, was played out. A lake, a mountain range or a valley, depicted in a realistic manner would make the viewer identify with the painting. With enough detail, the viewer could find any number of things reminiscent of the local village, farm or pasture. The journey of discovery would make the viewer not only feel a kinship with the work but also a sense of conviction that the work was real. The authenticity of the landscape contributed to disseminating the gospel by convincing the viewer that the sacred message contained therein was valid, be it Christ's birth or crucifixion or an episode in the life of a saint. And so, the depiction of these sacred scenes acted as a catalyst for changes in Western piety and Western art (Moleta, 1983).

Considering how venerated Francis was, one would think that Giotto would portray him as a sacred figure surrounded by elegant surroundings or embellished churches worthy of exalted adoration. But Giotto could not do this because of the way Francis lived. The stories and legends pertaining to his life and the humble places which he inhabited required Giotto to place him in nature to depict his life accurately. So, 


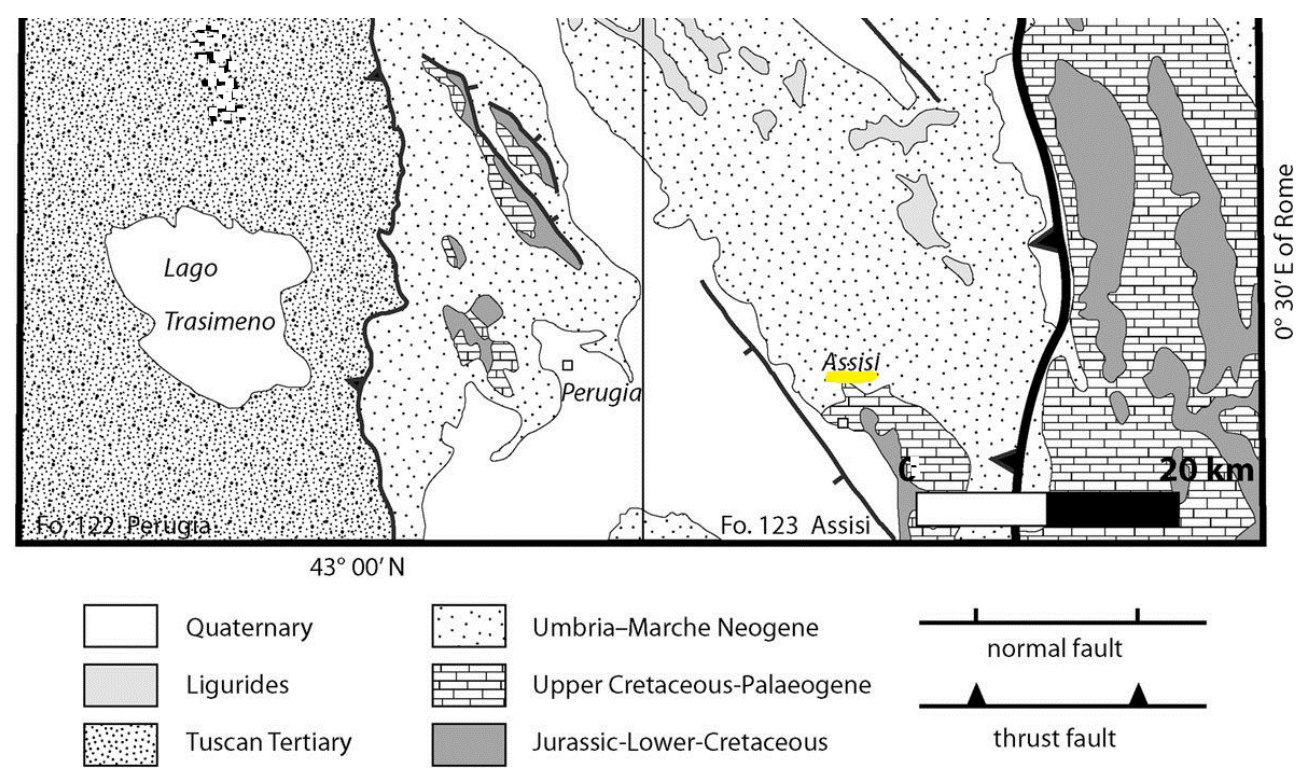

Figure 4. Geologic map of the area around Assisi. After Lena et al. (2014), Geological Society, London (November 2014).

we see in Giotto's works the visual story of the ecological movement started by Francis.

In looking at the geology of central Italy, which Giotto portrayed in the scenes of the life of St. Francis, we can see that he had a keen eye for geologic formations and took the time to portray them realistically. These regions have some of the most complex geology in the world, for the Apennine Mountains are not only seismically active but are being contorted by forces of both compression and extension. There are faults, upthrusts and nappes in the area, all of which displace strata, making it difficult for geologists to interpret the regional geology. Yet in Giotto's works we see that he found these unique geologic formations perfect for providing visual interest, and he depicted them accurately enough for geologists to identify the rock types and speculate as to the exact location represented in the scenes. To better understand the placement of the selected Franciscan monasteries and Giotto's portrayal of the landscape, refer to the geologic maps (Figs. 4, 5 6).

\subsection{Geology}

The Apennines, which form the backbone of the peninsula, are some $1200 \mathrm{~km}$ in length. They were formed some $20 \mathrm{Mya}$ by processes which have not been completely understood, even today, in that they were formed both by compression and extension. In the east, anticlinal ridges formed from thrust faults created a series of progressive folds, one after another, while in the west, fault block mountains were created by normal faults which slice out of the deep crust (Pizzorusso, 2013).

The folds in the Apennines are caused by thrust faulting (Fig. 3), where the thrust cuts upward at about a $30^{\circ}$ angle called a ramp. This wedge of thrust-up rock is forced into the shape of an anticline, and thus, the Apennine ridges are ramp anticlines. This range of large anticlinal folds includes Monte Subasio, the location of Assisi (Lena et al., 2014). They extend from southwest to northeast. This orderly sequence occurs when the material deposited while building the anticline becomes too large for continued displacement, and the thrust fault slices a new ramp along weaker strata. The process continues with a set of parallel folds visible at the surface, forming propagating fold-thrust belts which slice out of the deep crust (Alvarez, 2008).

In the Apennines, as the migrating compressional front moves northeastward (the anticlines become younger from Gubbio to the Adriatic Sea), there is an extensional front following behind (about $100 \mathrm{~km}$ to the rear). When the extensional front arrives, the fold is cut apart by normal faults and subsides as the underlying strata is stretched thin. The most likely explanation for this dynamic is that the lower part of the continental crust peels off and sinks. This hypothetical process is called delamination (Alvarez, 2008).

As noted previously (Fig. 2), the Scaglia Rossa limestone was used in the construction of the basilica of St. Francis in Assisi. But, amazingly, this limestone would provide the material for researchers to more accurately date the movement of continents and further their knowledge about the rate at which geologic change occurred.

The Scaglia Rossa is a pelagic sedimentary rock composed of $1 \%-20 \%$ foraminifera and $5 \%$ clay in a coccolith matrix, deposited from the Late Cretaceous to Middle Eocene. Its color ranges from brick red to pink and also gray, yellow and mixed white and pink. The red and pink colors are due to the oxidation of the iron minerals of limonite and hematite. Because its deposition was undisturbed by erosional gaps, and it 


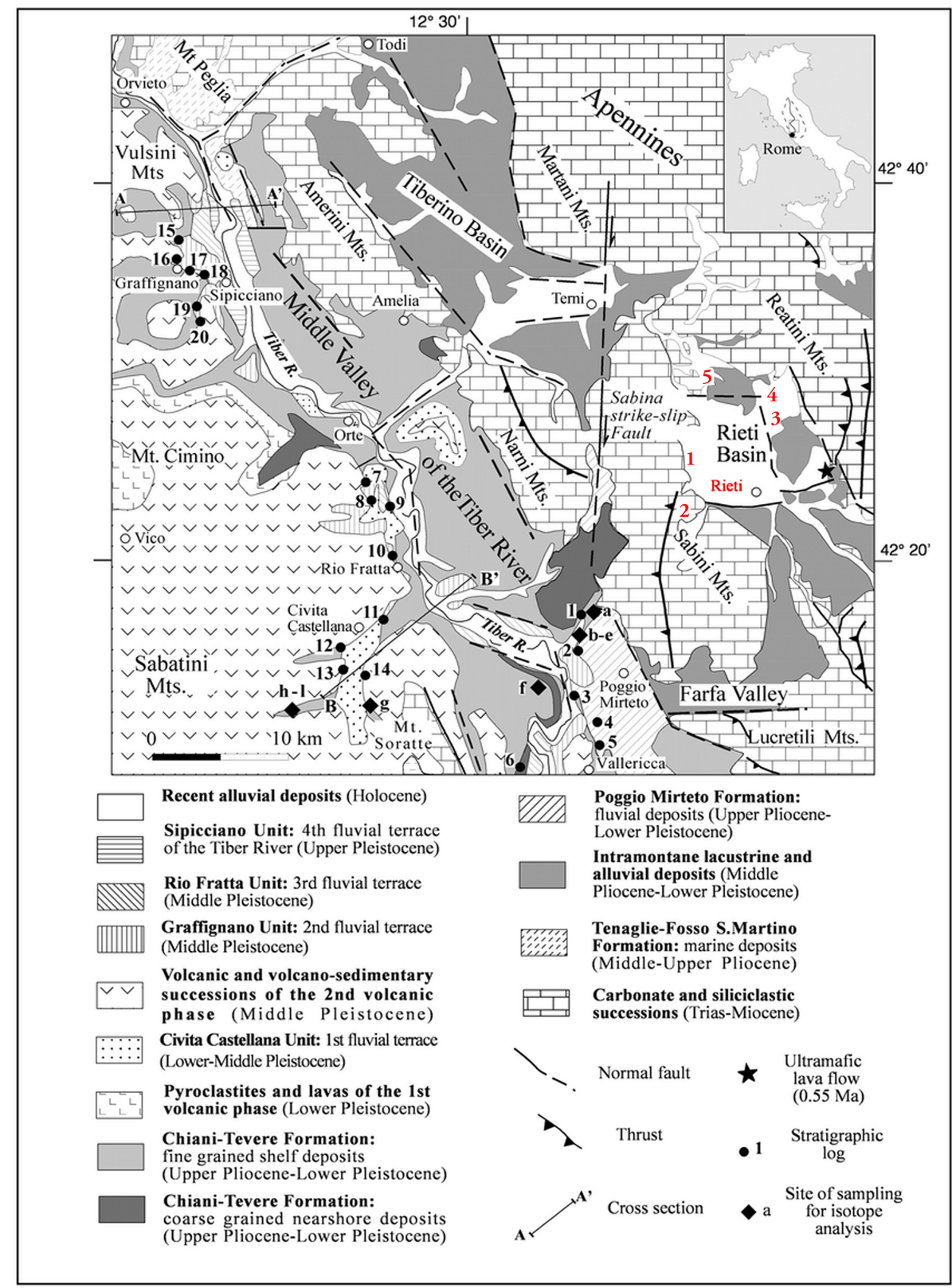

Figure 5. Franciscan monasteries (in red), including (1) Greccio, (2) Santuario di Fonte Colombo, (3) Santuario della Foresta, (4) Poggio Bustone and (5) Labro. After Mancini and Cavinato (2009).

was filled with plankton suited for dating and correlation over long distances, it carried a record of magnetic field reversals which allowed researchers to obtain data on $100 \mathrm{Myr}$ of geomagnetic polarity stratigraphy (from ca. 137 to ca. $23 \mathrm{Ma}$ ). This data was then used to affix dates on reconstructed maps of the continental positions since the breakup of Pangaea (Alvarez, 2009).

Some 65 Mya, a giant meteorite hit the Earth, sending smoke, dust and a rare element, iridium, into the atmosphere. The pollution blocked the Sun, which resulted in widespread plant and animal death on Earth, including the dinosaurs. Re- markably, high levels of iridium (ca. 455 parts per billion (ppb) in a meteorite vs. ca. 0.3 ppb in the Earth's crust), indicative of a meteorite strike, were found in the Scaglia Rossa strata dating to $65 \mathrm{Mya}$, the approximate time of the extinction of the dinosaurs (Alvarez, 2008).

Another unusual landform with a unique stratigraphy found in the area are foreign rocks of many different ages are called Ligurides. They were deposited in an ocean to the west of Italy - one that no longer exists. They are composed of turbidites and pieces of ocean crust, dating from Triassic to Eocene, that were displaced when the ocean was squeezed 


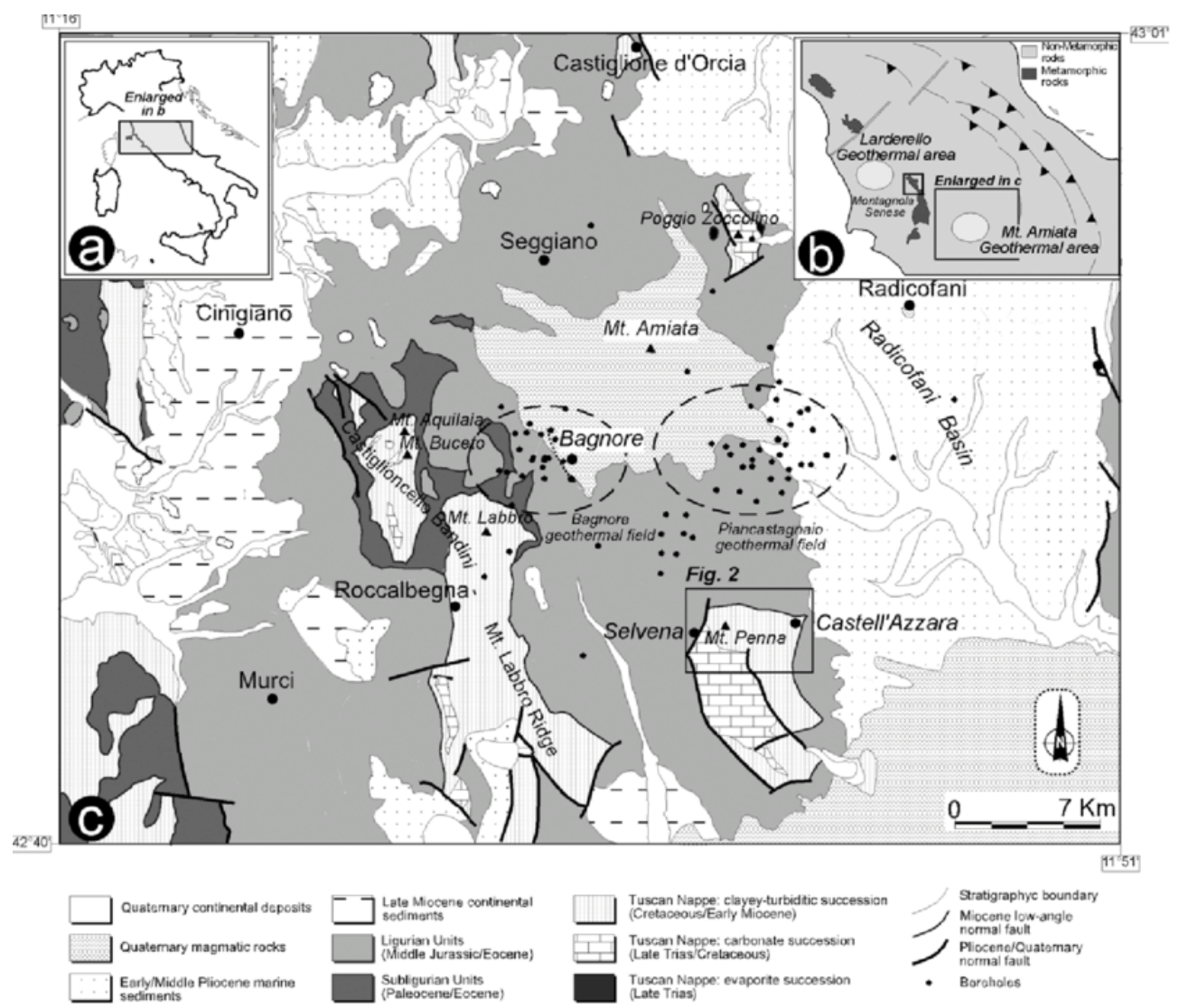

Figure 6. The monastery at La Verna sits on Mt. Penna (see also Fig. 17), a Miocene calcarenite. It is highly fractured, and many caverns and clefts are etched into its surface. Boulders and scree surround the base of the mountain. It rests on Cretaceous successions belonging to the eastern Ligurian units (Sillano Formation; Early Cretaceous). After Brogi and Fabbrini (2010).

shut. They have slid almost the entire way across the Italian peninsula. As underlying anticlinal ridges rose, the fragments would slide down the front toward the northeast. Sometimes they are badly damaged, and sometimes they are found in enormous blocks (Alvarez, 2008).

In the area around Assisi (Fig. 4), Mt. Subasio, is an anticlinal fold of marine limestone (pink, cream and gray), formed 10-15 Mya, which dominates the landscape. The structural setting is complex as it is cut in half by normal faults. Today, the eastern half of the anticline stands while the western half dropped down to the valley below the town. The area is seismically active. The basilica of St. Francis of Assisi was constructed with Mt. Subasio's pink Scaglia Rossa limestone (Lena et al., 2014).

The Rieti basin (Figs. 5, 10, 11) is an intramontane depression of the Apennine chain and home to a number of Franciscan monasteries. It is filled with continental Plio-Quaternary sediments made of conglomerates, sands, silts and travertine deposits that reach a thickness of $400-500 \mathrm{~m}$. The origin and evolution of the Rieti basin is related to the postcollisional extensional tectonics that have strongly affected this section of the Apennine orogenic belt since the Pliocene.
From the middle Pleistocene to the present, along the course of the Velino river, numerous travertine thresholds accreted, controlled by alternating erosional and sedimentary phases (Mancini and Cavinato 2009).

As to the lithologic commentary on the artworks, the following are the types of deposits which can be seen aboveground in the referenced areas: travertine, conglomerates, sands, silts, dolomite, limestone, fluvio-lacustrine deposits, turbidites, carbonates, calcareous tufa, evaporates, anhydrites, dolostones, marls and sandstone (basement crystalline and volcanic rocks, which cannot be seen, have been left out). The oldest aboveground deposits date to the Triassic (252201 Mya; Carrara et al., 2004).

Comments on the strata will be categorized based on color, form and congruity with the known geologic conditions in the area since the exact lithology in a Giotto work cannot be determined with certainty.

For scenes depicting events in the region of the Holy Land, the rocks Giotto portrays are devoid of vegetation, reflective of the desert environment, all the while showing bedding planes, erosional features and other realistic details. 


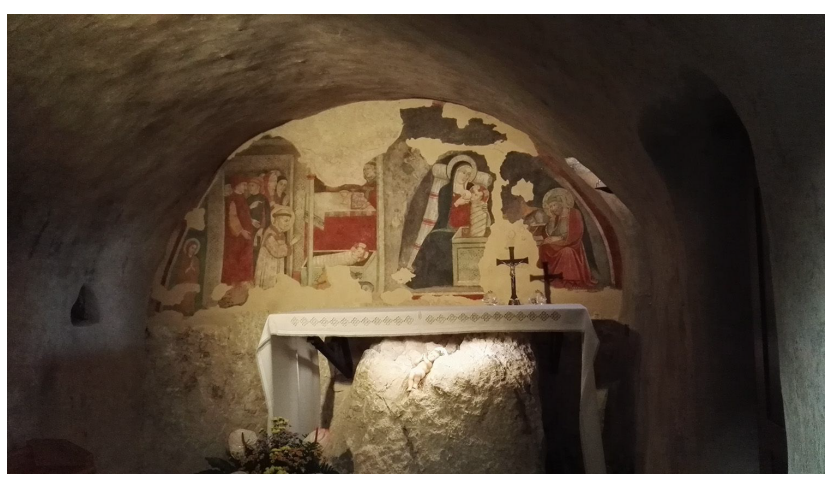

Figure 7. Limestone grotto at the monastery at Greccio, the site of the first nativity scene organized by St. Francis for Christmas in 1223. The limestone outcrop was the original altar before another was placed above it when the Pope visited. The 14th century frescoes depict the original nativity scene. Photo credit: Ann C. Pizzorusso.

The following works by Giotto are a small sampling of his extraordinary output. They were chosen because of his inclusion of geologic formations and natural elements.

\subsection{Nativity}

Francis staged the first living Nativity scene or "presepe" for Christmas in 1223 in a limestone grotto at his monastery at Greccio (Fig. 7). Interestingly, Francis had to obtain papal permission to use an ox and an ass in the manger scene to avoid the charge of novelty. Once approved, he invited the local townspeople, along with their animals, to participate in a recreation of the holy event. He situated the participants, including livestock, in the grotto and then placed a newborn in a manger cushioned with hay. Afterward, Francis stepped forward and led a celebratory mass. The altar was a block of limestone, which is still visible today. This brought the message of Jesus' birth down to Earth so that the lowliest person could identify with the humble manner in which he was born.

If we look at a Byzantine representation of the nativity (first part of the 14th century; Fig. 8) we can see Jesus' birth depicted in a cavern in a landscape complete with rocks, mountains and trees. The Byzantine style, lacking perspective and scale, portrayed the figures and landscape elements one-dimensionally, configured in a single plane (Dall'Asta, 2012). In religious art, this effectively created a psychological distance between the sacred events and the viewer, evoking a reverential experience.

Giotto revolutionized art by taking Byzantine iconography and humanizing it (Fig. 9). Following Francis' lead, the nativity thus became a natural event. Using elementary perspective techniques, he was able to compose a sacred scene that appeared similar to a person's daily life. In this way, the viewer had a direct experience with the miraculous, allowing the viewer to internalize the supernatural event and ulti-

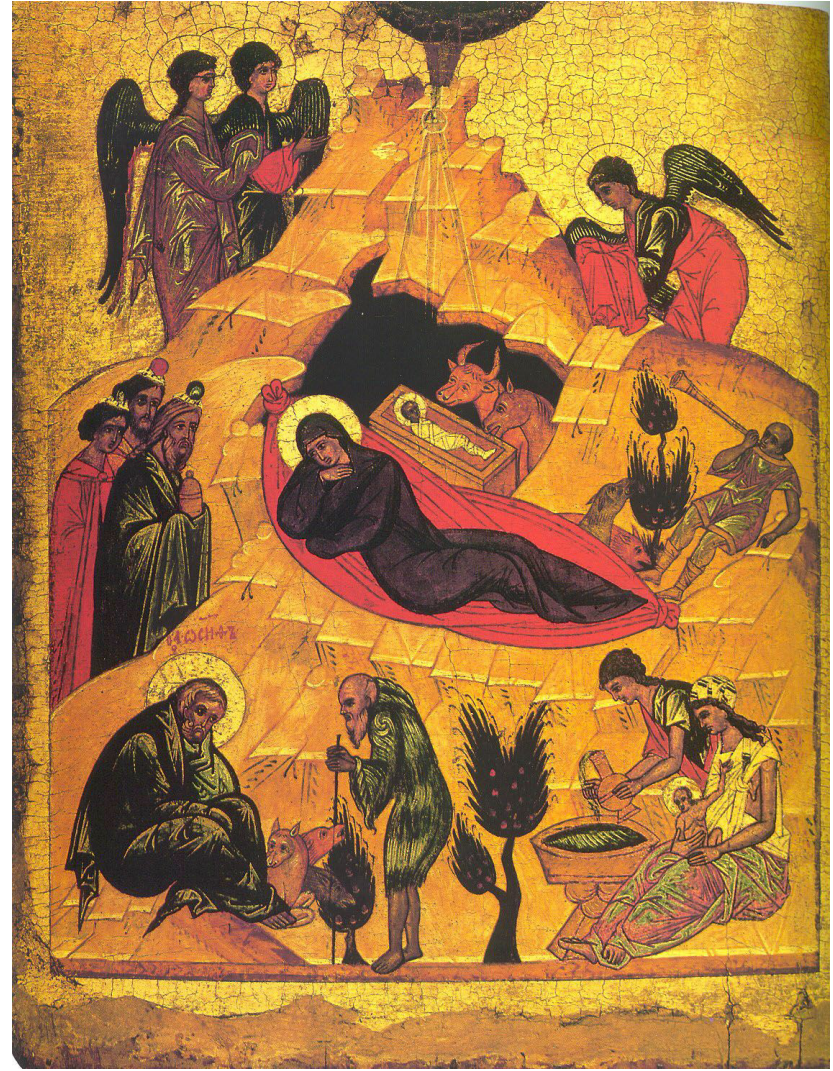

Figure 8. Nativity by Andrei Rublev. Note how the figures are onedimensional, and the entire work lacks perspective. Painted during the first half of 14th century and now at the State Tretyakov Gallery, Moscow, Russia. Source: public domain - Wiki Commons.

mately transfigure the human consciousness into a vessel for the divine (Panofsky, 1997).

Giotto also revolutionized the depiction of natural elements, by including them as vital to the composition, and also applying the same techniques (perspective, shading, etc.) on them as he used on his figures. This rendered the scene realistic, and the location was often identifiable to the locals. In his portrayal of the nativity, he reproduced the geology of the area surrounding the monastery at Greccio (Figs. 10, 11), which consists of carbonate units of the Sabina Sequence (Meso-Cenozoic; Carrara et al., 2004; Falcetti et al., 2014).

He depicted a limestone ledge and added a rudimentary wooden roof for shelter. The limestone strata in the background are upthrust, as shown by the vertical relief. These blocks, formed by the dynamic movement of the Earth, now act as a sheltering backdrop for the manger holding the newborn. Angels also hover overhead to protect, pray and rejoice at the miraculous event. The ox and donkey on the left are farm animals, vital to the sustenance of the people. The sheep, goats and their shepherds were also common to the area. Today, at the monastery at Greccio (Fig. 10), one can 


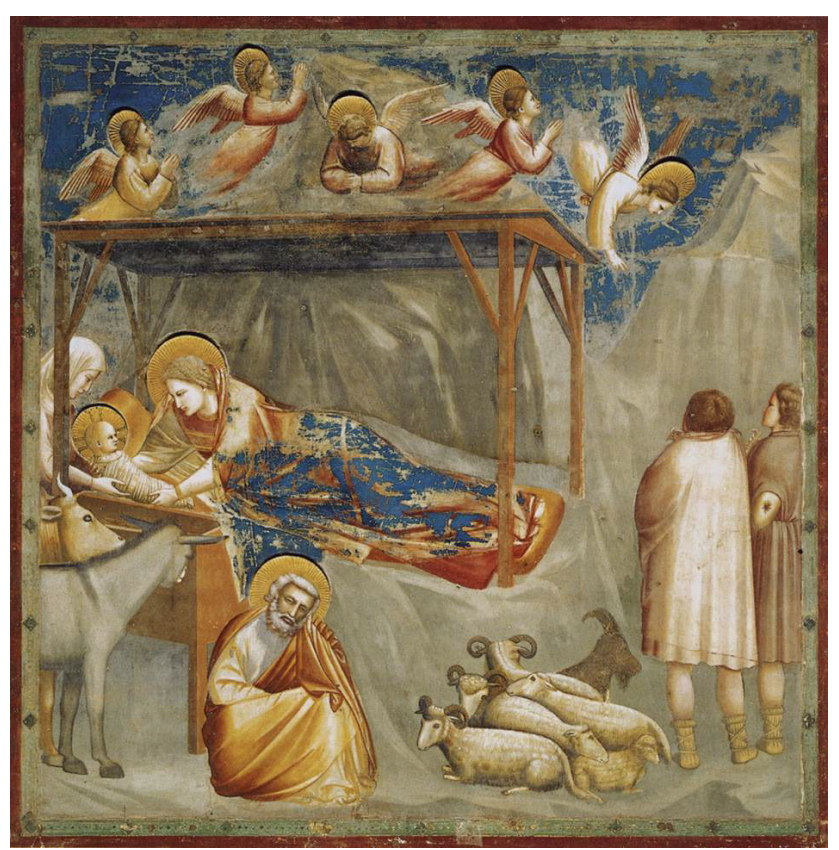

Figure 9. Nativity by Giotto (1303-1306 CE) at the Scrovegni (Arena) Chapel, Padua, Italy. Source: public domain - Wiki Commons.

see the limestone cliffs, crevasses and the original grotto that inspired St. Francis.

In describing the nativity, we are told that Mary and Joseph embarked on a journey, that the night was cold and starry and that there was no room in an inn nor help with the birth. The lowly manger was filled with hay, and animals were settling in for the night. Here, we see that Giotto continues the theme of Jesus' birth in a limestone landscape (Fig. 12). The upthrust block in the background provides shelter for the newborn set upon an altar-like formation of the bedrock in the foreground. And so, Jesus was born without fanfare as people went about their daily tasks. He did not stop the world; rather, he changed its orientation and sensibility. People continued to eat, talk, work, live and die, yet the birth of Jesus changed the intrinsic purpose of their actions and their lives. Placing Jesus in a manger, the locus where animals were fed, let us know that he would provide us with food as well (his body). The gospel of St. John 1:9 tells us that "there came into the world the true light [external light] which illuminates every man", meaning that, with the birth of Jesus, divine light appeared on Earth and was the vehicle used to communicate the gift of divine life. In the story of creation, the contrast between darkness and light was used as a metaphor. Now, in the mystery of the nativity, it returned and was transfigured into a more intimate form (might be considered internal light) in which God enters into the lives of people to create a second definitive creation. John $8: 12$ says "I am the light of the world; he who follows me does not walk in darkness but will have the light of his life." Giotto deftly incorporated light

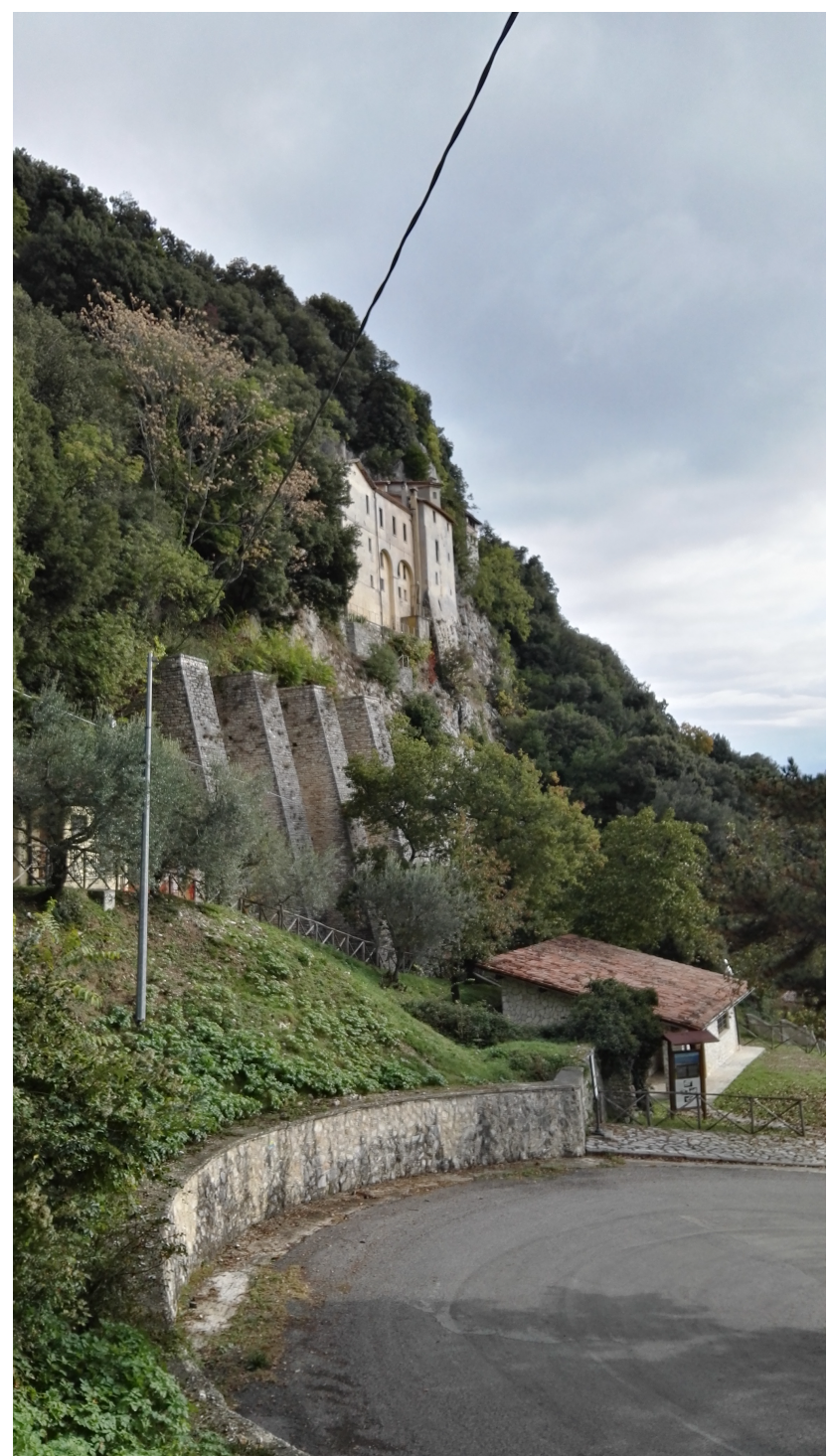

Figure 10. View of the monastery in Greccio, Italy, and the location of the first living nativity scene organized by St. Francis in 1223. The monastery is located along a thrust fault and is built on carbonate units of the Sabina sequence (Meso-Cenozoic). See the geologic map in Fig. 5. Photo credit: Ann C. Pizzorusso.

into his scenes to illustrate gospel teachings and miraculous events.

Another revolution in the portrayal of the nativity was the change, in the 14th century, from the use of a cavern, to a inn (kataluma) as described in the gospel of Luke. From that, the location was often a diversorium which might be an inn, a cabin (capanna) or a hut with a canopy (tettoia) which were common in medieval cities (Dall'Asta, 2012). These were public places where people came to rest and talk. These became the new churches, humble and unpretentious, according to the reform principles of the Franciscans who longed to return to a simple evangelization. 


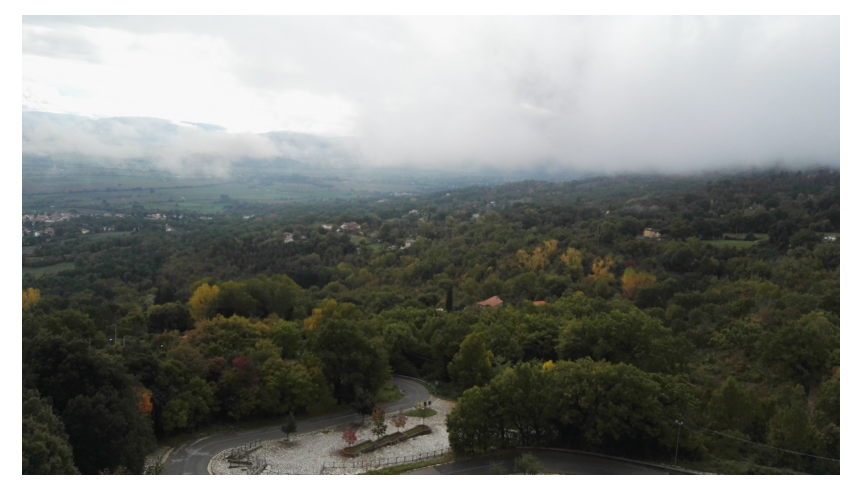

Figure 11. View from the monastery at Greccio, Italy, built on carbonates and looking out at the fluvio-lacustrine and fan deposits. Photo credit: Ann C. Pizzorusso.

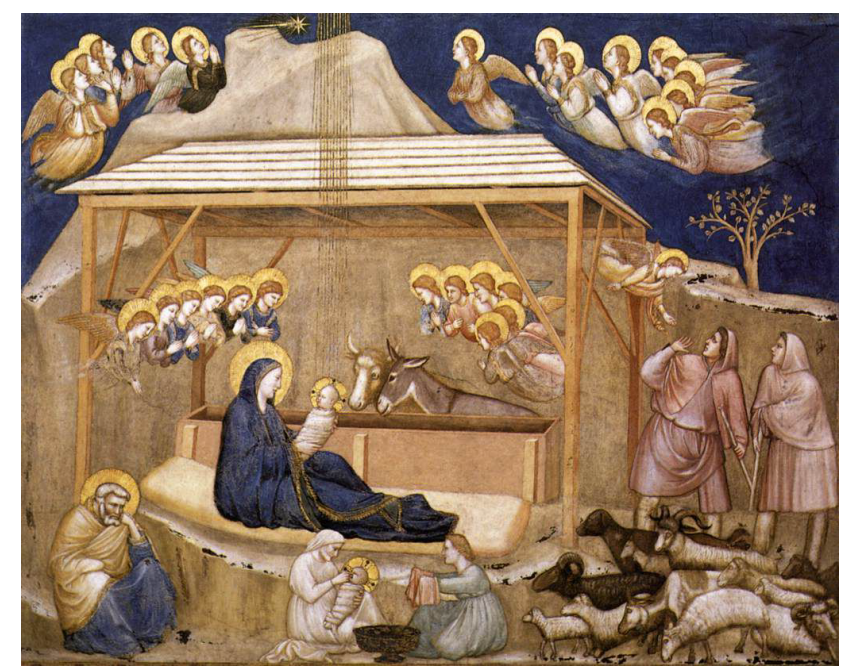

Figure 12. Nativity scene by Giotto, Lower Church, Assisi, Italy (ca. 1310). Source: public domain - Wiki Commons.

In this fresco, we move from a desert, an isolated locale, to an urban setting (Fig. 13). The abandonment of the desert and the grotto has a precise theological justification. By placing Jesus' birth in a city, not in the wilderness, the mystery of his divine nature would not be hidden from the people. He is portrayed as being born in a town, near a market, in an open, populated place where his nature can be seen by all.

The baby is often placed in the foreground, on the earth, underlining his human character, propped on a bale of hay (an allusion to the eucharistic bread) or on a sheet (evocative of the shroud). In this manner, if the faithful looked down, they would have understood the humility of the divine birth. From an etymological standpoint, the word humble (in Latin, humus) can be taken to mean attached to or close to the earth.

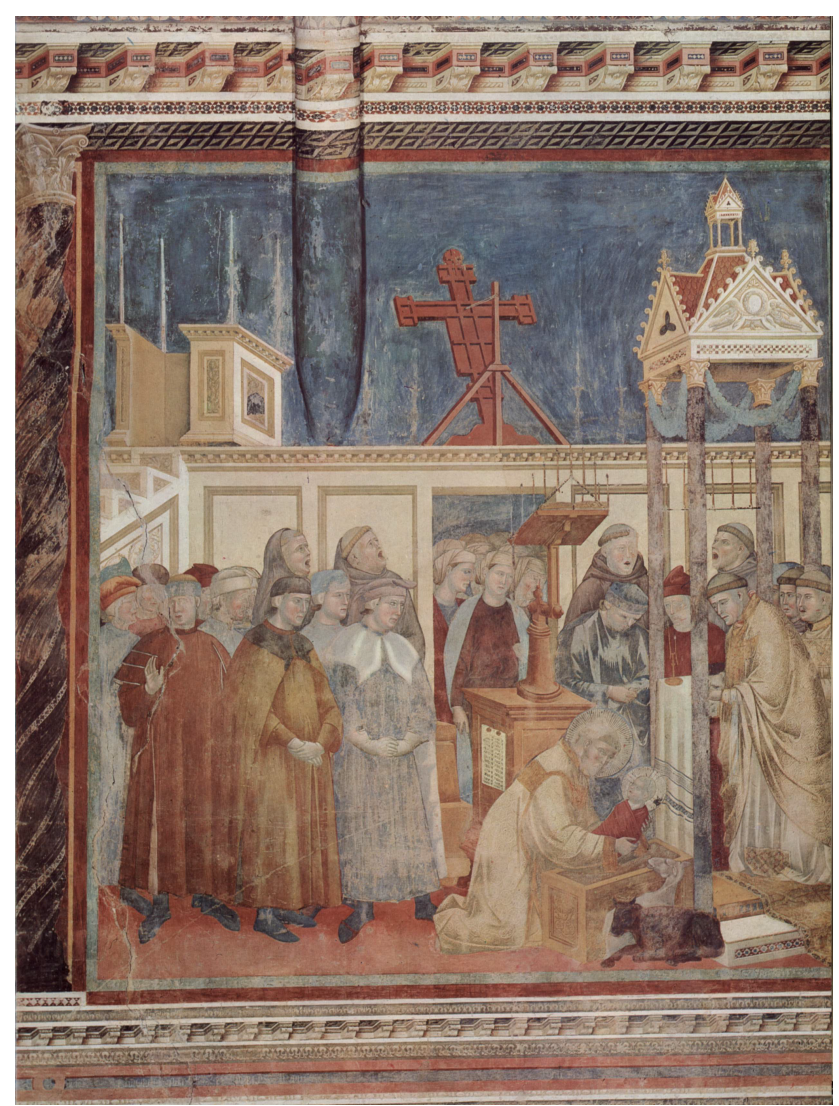

Figure 13. Nativity scene by Giotto (ca. 1297-1300). St. Francis Upper Church, Assisi, Italy. Note the change in locus from the outdoor manger to an urban, interior, populated, public church. Source: public domain - Wiki Commons.

\subsection{Preaching to the birds}

In Byzantine art, the background was usually gold, a glorious, expensive color which invoked a sense of awe of the divine and, as a result, kept the viewer at a reverential distance (Dall'Asta, 2012). As a color, it was flat, which did not draw the viewer into the scene. Giotto's treatment of this event (Fig. 14) is very interesting because of his use of a gold background. The gold finish is textured and shaded, and the dark foreground cuts a horizontal band, imparting depth and $3 \mathrm{D}$. He then places the tree in a manner in which it is growing out of the picture. St. Francis is preaching to birds, who are walking and flying toward him, seemingly enraptured by his words. Due to the use of color, shading and perspective, Giotto created a work that had volume and movement. The tree is swaying in the wind, the birds are flying and walking and the friar behind St. Francis is in a different plane, giving the whole picture a sense of depth and dynamism. The warm colors invoke an autumn day with an orange-gold sun illuminating the background, while the use of earth tones and touches of dark gray-greens give the work a cohesiveness, warmth and intimacy. One wants to watch, an experience we 


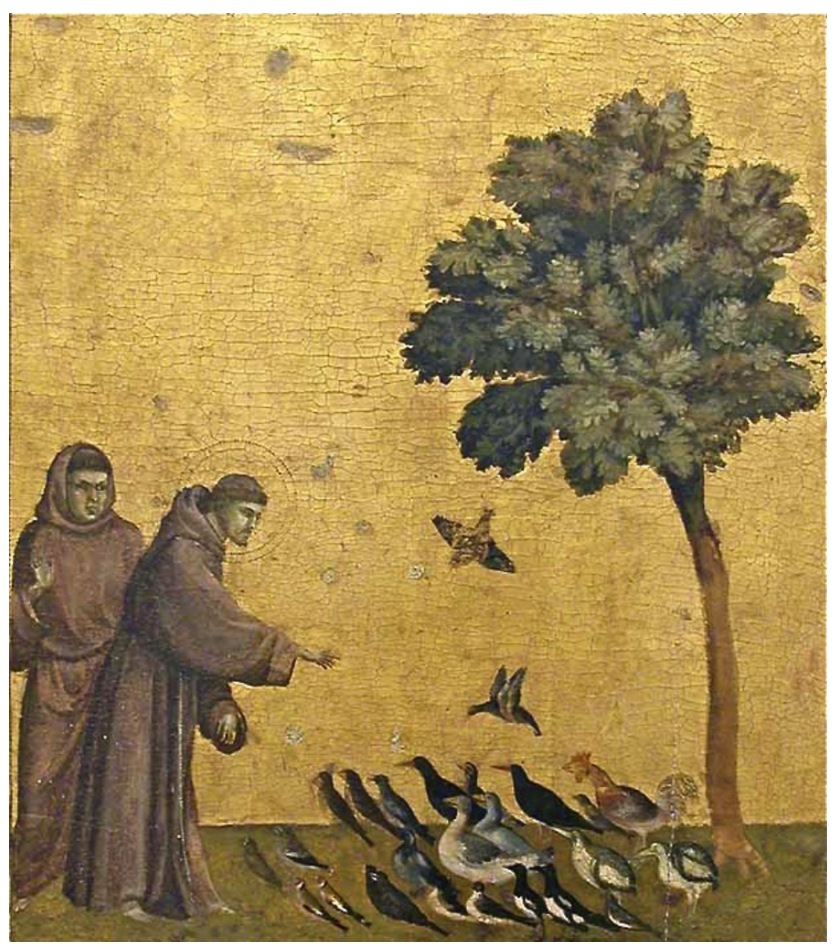

Figure 14. St. Francis preaching to the birds by Giotto (12951300). Now at the Louvre Museum, Paris, France. Source: public domain - Wiki Commons.

have all had while viewing flocks of birds, yet one wants to be still and quiet so as to not disturb them lest they fly away. In this manner, Giotto works his magic, allowing us to feel the peace and mystical nature of God's Earth and his creations by presenting them in a simple setting that is reminiscent of our everyday life.

An incident illustrating Francis' benevolent attitude towards nature is recounted in Fioretti di San Francesco (Little Flowers of St. Francis), a collection of legends and folklore that was compiled after his death. One day, while Francis was traveling with some companions, they happened upon a place in the road where birds filled the trees. He told his companions to "wait for me while I go to preach to my sisters the birds". The birds surrounded him, intrigued by the power of his voice, and not one of them flew away.

\subsection{The flight into Egypt}

The Gospel of Matthew 2:13-23 recounts that, after the visit of the Magi to the newborn child, an angel appeared to Joseph in a dream and told him to flee to Egypt with Mary and Jesus as King Herod would attempt to kill the child. In this scene, Giotto portrays an arid landscape (Fig. 15). The mountains are sparsely vegetated, and the desert through which they are traveling is inhospitable. It is an arduous journey, with the donkey making its way along a narrow path with a steep precipice in the foreground. Joseph leads the way

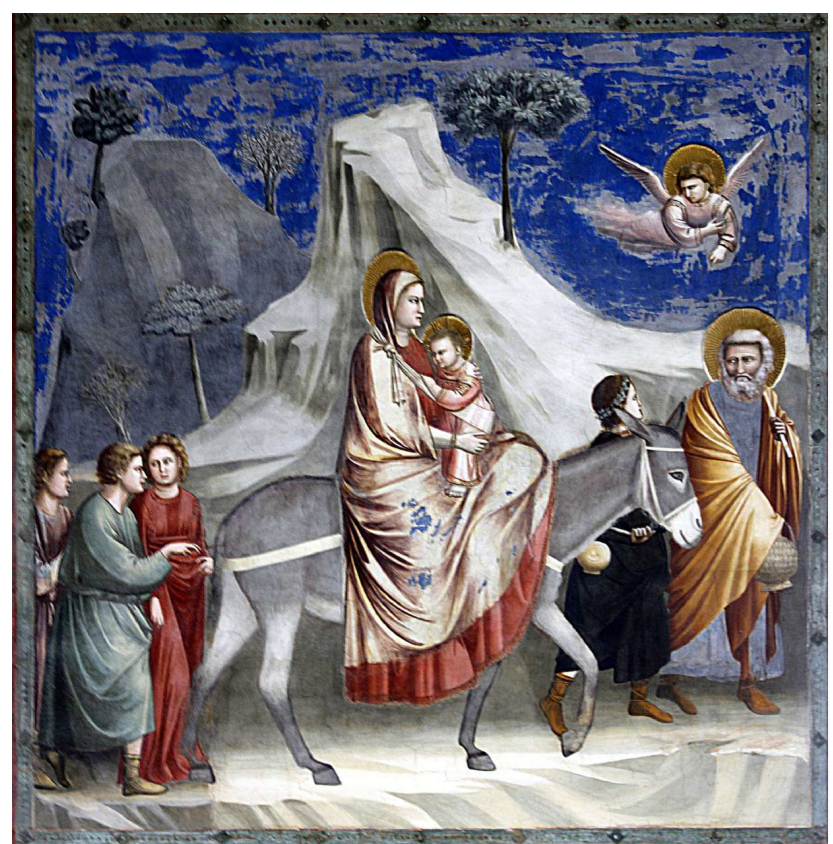

Figure 15. The flight into Egypt by Giotto (1304-1306). Scrovegni (Arena) Chapel, Padua, Italy. Source: public domain - Wiki Commons.

with an angel, most likely the one who appeared to him in the dream, guiding and protecting them on their way. Mary and the child sit upright, with great dignity, as they endure the harsh traveling conditions. Giotto chooses a background of gray and blue to impart the sensation of a rocky, barren landscape where even the few trees must struggle to survive. He pays attention to the rock strata and bedding planes so that the formations appear close to those we see in nature. The dark blue sky and impending darkness causes a sense of preoccupation for the welfare of the family. Were they traveling by night to avoid detection or to avoid the harsh sun? This is a mystery. Where will they rest? There are no buildings or indications they are close to a village or city. So, here, Giotto presents a barren, dark and uninviting environment that would have been unfamiliar to the Italians living in the florid Italian countryside. Yet, they would have been able to understand the hardship involved for a mother and newborn undertaking this journey on a donkey. The vast unknown terrain, with no water or vegetation to sustain them, leaves the viewer sympathizing with the Holy Family and respecting the sacrifice they made for our ultimate salvation.

\subsection{The dream of Joachim}

This touching scene shows St. Joachim, husband of St. Ann and father of the blessed Virgin Mary, in exile in the wilderness (Fig. 16). The landscape, colors, and posture of St. Joachim convey a profound sense of despair. St. Joachim and St. Ann had reached advanced ages without having a 
child. This was considered an indication of God's wrath. Joachim went to the temple to make a sacrifice, which was rejected, and he was then expelled by the rabbis. He went into exile in the mountains, leaving behind his wife, Ann. As we can see, Giotto places him in a hunched-over position, with his head resting on his knees. He is desperate and inconsolable. He sits directly on the ground; is he so weak or defeated that he no longer can or will get up? The landscape is stark, and a dark mountain with no vegetation rises menacingly in the background. The carbonate rocks in the fore and middle ground are lighter, reflecting their natural color, but arid, save for very few trees. The only people in view are the shepherds who frequented the mountains with their flocks. The small cabin is made of blocks of limestone likely mined from the local area. Perhaps it was the cabin (refugio) of the shepherd who used it at night? One of the sheep appears to be entering a grike (solution fissure). Giotto portrays the natural landscape here as barren, a metaphor for the fruitless matrimony of Joachim and Ann. He does a marvelous job of depicting the nearly vertical bedding planes of the dark brown formation, perhaps a bedded sandstone, in the distant background. Geologically, the beds were originally laid down flat, and with subsequent deformation and movement, they were thrust upward into their nearly vertical configuration. Giotto depicts the carbonates in the foreground as they appear in nature, i.e., blocky, with cracks and crevasses and, where it has been eroded by wind or rain, softer edges. Giotto creates a masterful geologic environment, paying careful attention to the physical characteristics of the different types of rock. What hope can there be in such an environment where there is no sign of fertility, no lush green plants, no water - nothing? There is something, however - the angel. It is bringing word to Joachim that Ann is with child, and she will be blessed. Joachim's world will change with this message, and our world will be changed as well.

\subsection{St. Francis receiving the stigmata}

The grotto of the monastery at La Verna was the place at which St. Francis received the stigmata of Christ in 1224. La Verna, where pilgrims still visit to pray and meditate today, is located on Mt. Penna (Fig. 6) in the Apennine ridge connecting Casentino and Valtiberina. In ancient times, people could not explain how this mount, a mass of limestone, came to be, so the legend was born that it (Mount Alvernia in Latin; geographically known as Mt. Penna) was created by a strong earthquake that occurred when Jesus died on the cross. Its geological origins are so complex that, even today, scholars are still trying to decipher it. However, research (Brogi and Fabbrini, 2010) indicates that Mt. Penna (Fig. 17) is composed of Miocene calcarenite resting Cretaceous successions belonging to the eastern Ligurian Units (Sillano Formation; Early Cretaceous).

In this image of solitary mystical experience (Fig. 18), Giotto portrays Francis on a block of limestone which has

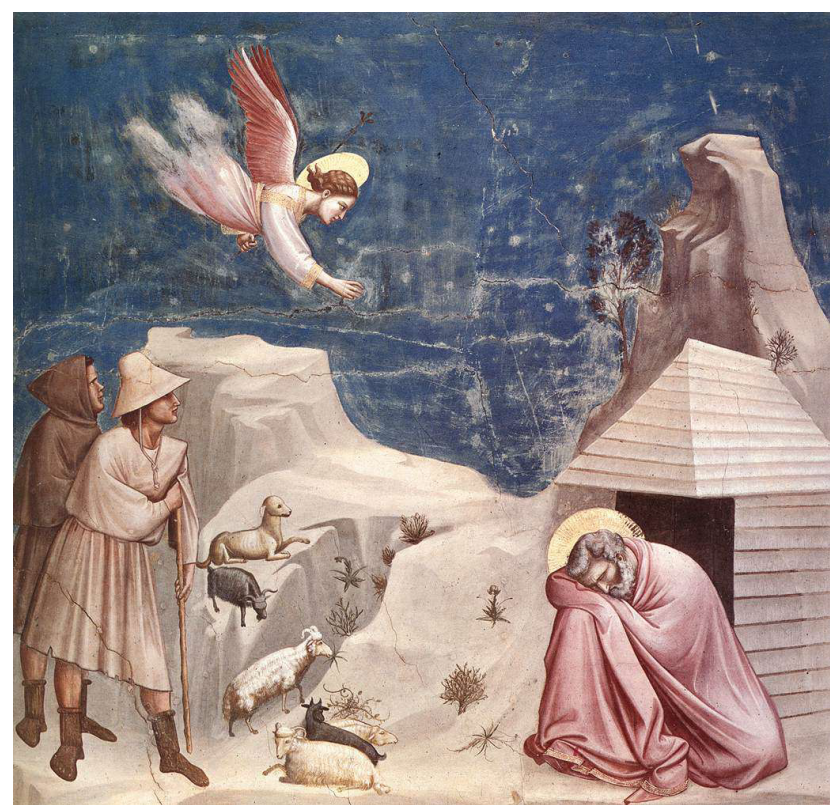

Figure 16. The dream of Joachim by Giotto (1304-1306). Scrovegni (Arena) Chapel, Padua, Italy. Source: public domain Wiki Commons.

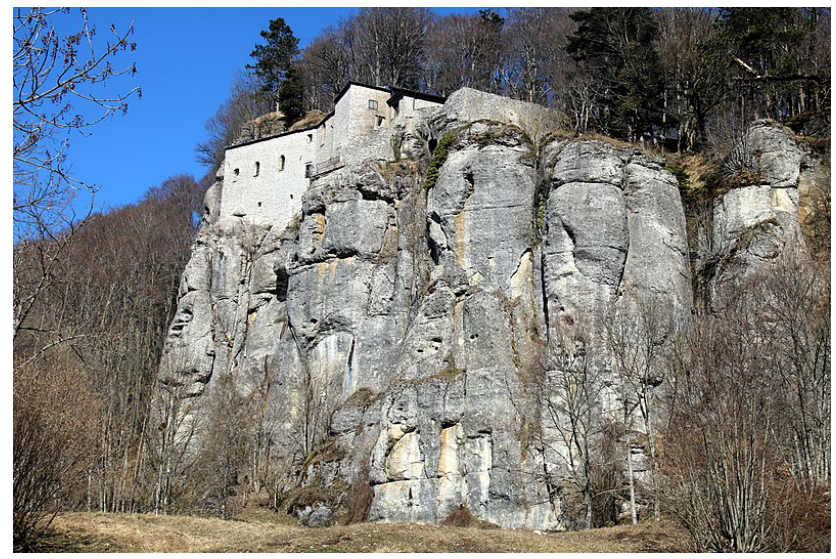

Figure 17. The monastery at La Verna, located on Mt. Penna, composed of Miocene calcarenite. Source: public domain - Wiki Commons.

been weathered and uplifted, as seen by its nearly vertical relief. A cleft in the side of the cliff, common to calcareous deposits, has opened. Giotto uses this rock, which has been sliced open, to imitate the wounds in St. Francis' hands and feet. The church in the foreground is made of the gray limestone found in the area and commonly used for construction. To the left of the church, grikes (solution fissures) and clints (limestone separated from adjacent sections by solution fissures) are starting to form. Behind the kneeling figure is the cave where, in one account, he struggled nightly with demons. Above the cave perches the falcon which woke him for his vigils and whose hovering flutter was an omen of the 


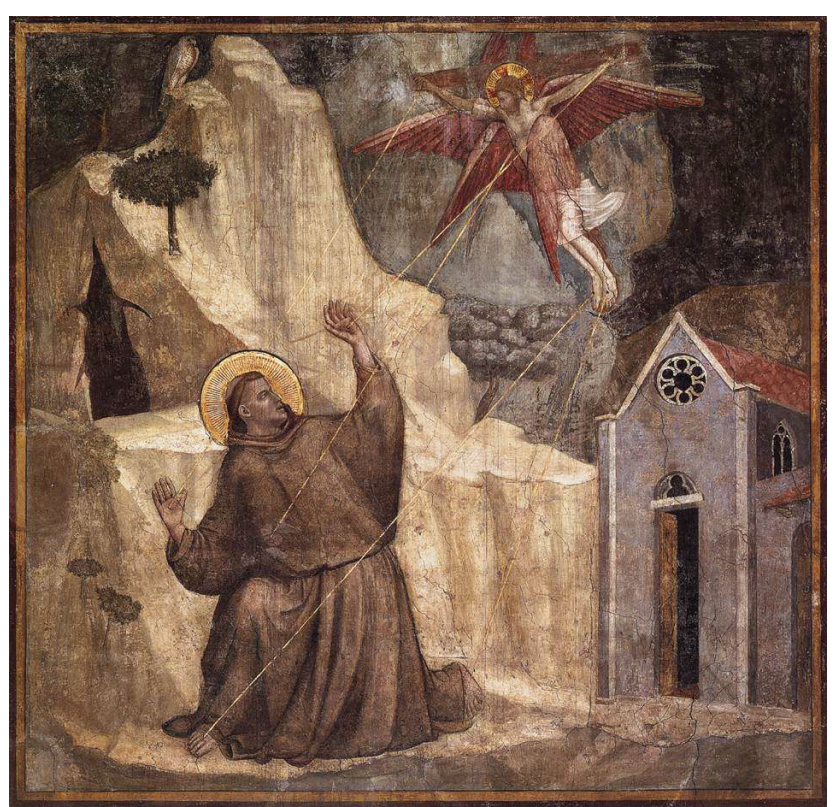

Figure 18. St. Francis receiving the stigmata by Giotto (1318). Bardi Chapel, Santa Croce Basilica, Florence, Italy. Source: public domain - Wiki Commons.

heights of contemplation to which Francis would soar. Flora and fauna are sparse, and the sky is a deep gray-black, forcing us to pay attention to the miracle that is playing out on this mountainside. The Franciscans used this location and the divine occurrence to demonstrate that mountains were vital in the sacred ritual, thus promulgating the idea that they would provide a nearness to God and a source of divine inspiration (Schama, 1995).

An excerpt from the anthology Fioretti di San Francesco (Little Flowers of St. Francis; Anonymous, 1979) describes this miracle as follows:

... considering the form of the mountain and marveling at the exceeding great clefts and caverns in the mighty rocks, he betook himself to prayer and it was revealed to him that those clefts ... had been miraculously made at the hour of the Passion of Christ when, according to the gospel, the rocks were rent asunder.

\subsection{St. Francis gives his mantle to a poor man}

In this scene, Francis demonstrates his commitment to refuting worldly goods by giving his mantle to a poor man (Fig. 19). He has abandoned his fine clothing and is now dressed in the simple sackcloth emblematic of the congregation of friars. This is an unwitnessed and spontaneous act which takes place in a rural setting. While art historians claim the town on the hill is Assisi, this would not be accurate as Assisi sits on the western edge of Monte Subasio, an anticlinal fold formed 10-15 Mya above the thrust ramps and cut in

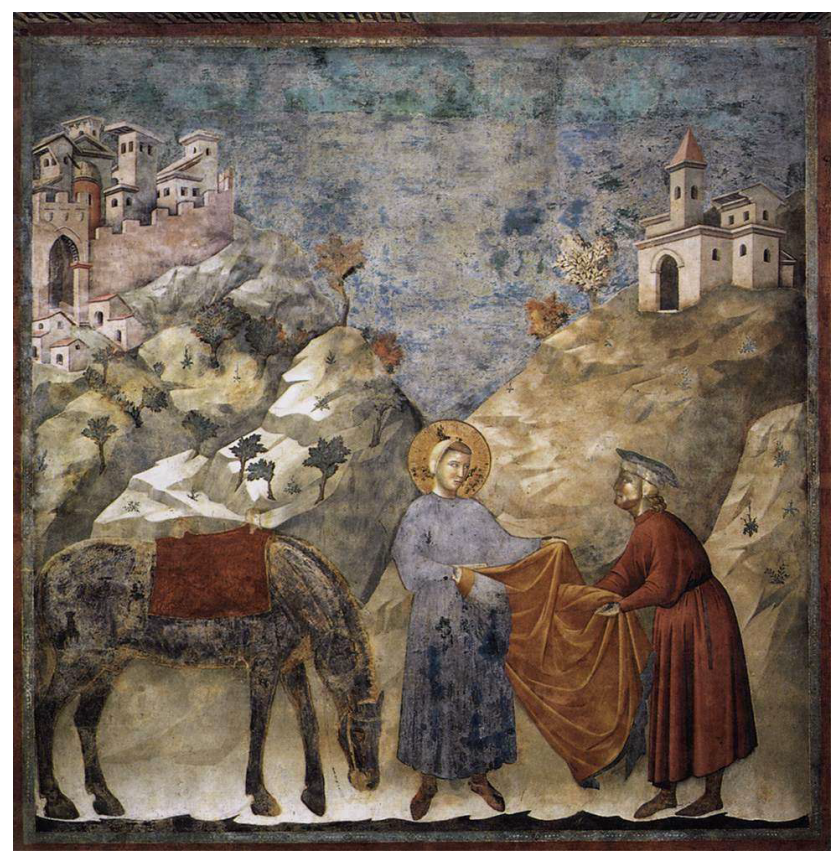

Figure 19. St. Francis gives his mantle to a poor man (1297-1299). Basilica of Saint Francis, Assisi, Italy. Source: public domain Wiki Commons.

half by normal faults as the extensional front passed through in the last few million years. And so, the Monte Subasio we see today is a half anticline, with the eastern half still standing and western half having dropped down to the valley to the west of the town (Alvarez, 2008). The actual site may be another location (there are many) or a montage used for dramatic effect, as Francis is placed at the midpoint between two hills, one with a town and the other with a monastery. He leaves one behind and moves unknowingly toward the other. Giotto uses perspective and scale to depict the town realistically in the distance, complete with the walls which surround it. Remnants of medieval walls such as these, constructed with local material, often limestone, can still be seen today. The towns were historically located on high ground for security. The finely detailed terrain is evocative of the countryside one can see today in central Italy. The rock formations are most likely limestone due to the color, blocky form, faults, grikes and clints. Enormous sections of strata were overturned and displaced as a result of thrust-block mountain building and continuous seismic activity in the region since Roman times (Guidoboni and Ferrari, 2000). The gorges and crevices still visible in many areas today are, for the most part, unnamed and are best seen untouched in the many national parks. But one, the Bottaccione gorge near Gubbio, is a mecca for geologists looking at the famous CretaceousTertiary (K-T) boundary in the Scaglia Rossa limestone.

It is said that Francis walked from one village to another, where he would preach. Giotto places him on a solitary path out of town. In this way, out of sight of anyone, he prac- 
ticed his charity anonymously and in the midst of nature. The colors Giotto uses are characteristic of limestone, ranging from milky white and ivory to light gray and pink. The towns would have been constructed with blocks of local calcareous rock, so the delicate pastels which characterize the buildings and walls are the actual color of the indigenous rock. In fact, many of the buildings in Giotto's frescoes are pink. The trees hang precariously on the slopes as they endeavor to insert their roots in crevasses and cracks. The misty blue sky is common to the area, where frequent rainfall and clouds add to the mystique of the atmosphere. A scene like this would resonate with any viewer as they would understand the landscape and recognize the local cities with their houses, churches and towers. They could see familiar mountain paths and remember their own difficult journeys, be they psychological, spiritual or corporeal. And so, through Francis' example, and ultimately through their own actions, seen or unseen, they could become saints as well.

\subsection{The legend of St. Francis: miracle of the spring}

St. Francis, retiring to pray in the wilderness during high summer, became ill and was forced to go by donkey (Fig. 20). When the farmer who owned the animal begged for water, Francis took pity on him and, after praying, struck a rock and water came bubbling out of the ground. Here, Giotto portrays the landscape in the foreground and middle of the picture with wave-like patterns formed by the erosion of stratified limestone, such as the Maiolica limestone found in many parts of Umbria (Galdenzi, 2013). In the background, large blocks have been displaced and turned upright when thrust faults sliced up through the Earth. The textures of the bedding planes and erosional patterns are realistic. In the foreground, St. Francis prays on what appears to be and inclined calcareous sinter terrace. In the foreground, we see a crevasse which was formed during the ongoing seismic or thrust-block mountain-building activity in the area. In the background, we see a dark area between the two rock formations which may be a fault. Limestone is porous, and often springs will gush forth from the interior of the Earth. The ground has been fractured and deformed, and many faults have caused the displacement of strata and fissures and crevasses. Interestingly, the Italian Secretary of Transportation, Riccardo Nencini, advanced an idea that the actual location of this spring is the cascade of the Rovigo torrent in Firenzuola. While this is not supported by geologic data, it is a tribute to the power of Giotto's imagery in that, after 700 years, people are still attempting to identify the landscapes he depicted.

\subsection{The enduring legacy of St. Francis and Giotto}

The frescoes, altar panels and paintings reflecting the new, naturalistic style also provided a visual accompaniment to the popular preaching approach practiced by St. Francis, not in Latin but in the spoken language (an Umbrian form of Ital-

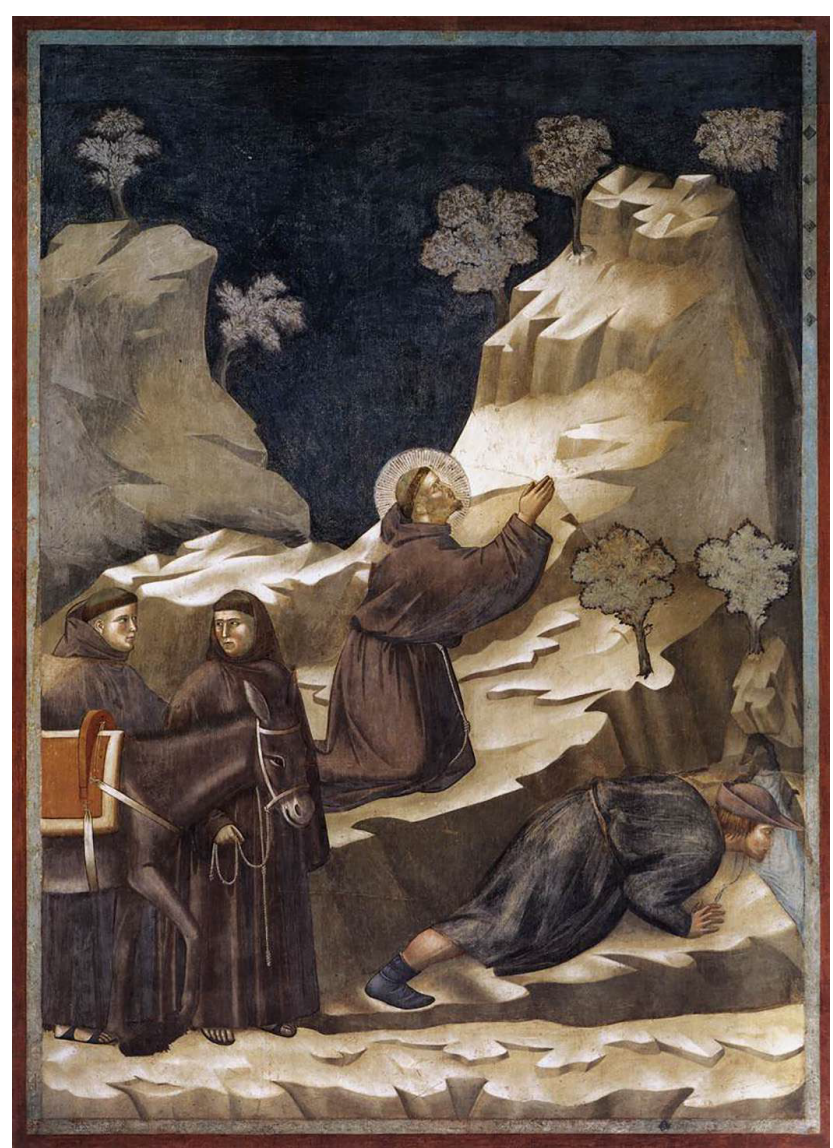

Figure 20. The legend of St. Francis - miracle of the spring (12971300). Upper Church, Assisi, Italy. Note the realistic depiction of the wave-like marks of erosion along the bedding planes of the stratified limestone. Source: public domain - Wiki Commons.

ian). Together, the visual and the audible messages centered on the mystery of the incarnation and on the need for repentance. In fact, the visual representation of nature was much more powerful than the written word as most people were illiterate, and texts available for study, were for the most part, ancient or ecclesiastical. Aristotle, Pliny and others formed the basis of natural philosophy, and their ideas had not been altered or challenged in 1500 years (Grant, 2010). With the arrival of St. Francis and Giotto, however, a shift in thinking resulted in massive changes in many disciplines, and nature was one of them (Schama, 1995). When texts on nature started to be published in the Renaissance, the ideas they set forth were very late in arriving for the ecological and natural history ideas of St. Francis as represented artistically by Giotto had already been absorbed into the psyche of the common people for over 200 years.

Some 750 years after the saint's death, on 29 November 1979, Pope John Paul II declared St. Francis the patron saint of ecology. Successive Popes, Benedict XVI and Francis, continue to use St. Francis as a model in their public comments over the years, as follows: 
... not to behave like dissident predators where nature is concerned, but to assume responsibility for it, taking all care so that everything stays healthy and integrated, so as to offer a welcoming and friendly environment even to those who succeed us.

As a friend of the poor who was loved by God's creatures, St. Francis invited all of creation - animals, plants, natural forces, even Brother Sun and Sister Moon - to give honor and praise to the Lord. The poor man of Assisi gives us striking witness that when we are at peace with God we are better able to devote ourselves to building up that peace with all creation which is inseparable from peace among all peoples.

It is my hope that the inspiration of Saint Francis will help us to keep ever alive a sense of "fraternity" with all those good and beautiful things which Almighty God has created.

St. Francis teaches us that the world of God and the world of nature are one.

\section{Conclusions}

St. Francis and Giotto, two revolutionary figures who never knew each other, were linked by history and art. Unbeknownst to them, their legacy would ultimately change Western piety, art and natural history. Much of today's ecological movement has embraced the tenets espoused by St. Francis. Giotto not only immortalized St. Francis' idea of the sacredness of nature by carefully placing and configuring geological elements realistically in his frescoes, he provided a lasting visual record which allows modern researchers a basis for further study. Not only can they identify the landforms of central Italy, one of the most complicated areas in the world, they also know that Giotto's pastel colored buildings were not flights of fancy but duplicated the colors of the indigenous pink, gray and ivory limestone actually used in medieval construction. Amazingly, the use of the pink Scaglia Rossa limestone to build the Basilica of St. Francis would end up being the key to unlocking many mysteries in the history of geology. So while researchers continue to study the outcrops and mountains on which St. Francis built his monasteries, they will also learn that these outcrops were, and still are, miraculously sacred sites. And so, central Italy seems to be a geologist's paradise, where one can participate in the realm of art and religion by looking at Giotto's frescoes and unlock the Earth's mysteries while walking in the footsteps of St. Francis. 
Appendix A: Definitions (source: Wikipedia)

Anticline

Calcarenite

Coccoliths

Conglomerate

Fault

Fault blocks

Foraminifera

Marl or marlstone

Turbidite

Orogeny

Scree

Tectonics

Thrust fault

Travertine
A type of fold that has an arch-like shape and has its oldest beds at its core in structural geology. A type of limestone that is composed predominantly, with more than $50 \%$, of detrital (transported) sand-sized ( 0.0625 to $2 \mathrm{~mm}$ in diameter) carbonate grains. The grains consist of sandsized grains of either corals, shells, pellets, fragments of older limestones and dolomites, other carbonate grains or some combination of these. Calcarenite is the carbonate equivalent of a sandstone.

The individual plates of calcium carbonate formed by coccolithophores (single-celled algae such as Emiliania huxleyi), which are arranged around them in a coccosphere.

A coarse-grained clastic sedimentary rock that is composed of a substantial fraction of rounded to subangular gravel-sized clasts, e.g., granules, pebbles, cobbles and boulders, larger than $2 \mathrm{~mm}$ in diameter.

A planar fracture or discontinuity in a volume of rock across which there has been significant displacement as a result of rock mass movement.

The very large blocks of rock, sometimes hundreds of kilometers in extent, created by tectonic and localized stresses in the Earth's crust.

The members of a phylum or class of amoeboid protists (informally called forams), characterized by streaming granular ectoplasm for catching food and other uses, commonly having an external shell (called a test) of diverse forms and materials.

A calcium carbonate or lime-rich mud or mudstone which contains variable amounts of clays and silt. The dominant carbonate mineral in most marls is calcite, but other carbonate minerals such as aragonite, dolomite and siderite may be present.

The geologic deposit of a turbidity current, which is a type of sediment gravity flow responsible for distributing vast amounts of clastic sediment into the deep ocean. The primary mechanism by which mountains are built on continents.

A collection of broken rock fragments at the base of crags, mountain cliffs, volcanoes or valley shoulders that has accumulated through periodic rockfall from adjacent cliff faces.

The process that controls the structure and properties of the Earth's crust and its evolution through time. In particular, it describes the processes of mountain building.

A break in the Earth's crust across which older rocks are pushed above younger rocks.

A form of limestone deposited by mineral springs, especially hot springs. 
Data availability. All data are freely available online and are part of the public domain.

Competing interests. The author declares that there is no conflict of interest.

Special issue statement. This article is part of the special issue "Five years of Earth sciences and art at the EGU (2015-2019)". It is a result of the EGU General Assembly 2018, Vienna, Austria, 8-13 April 2018.

Review statement. This paper was edited by Tiziana Lanza and reviewed by Martin Bohle and one anonymous referee.

\section{References}

Alvarez, W.: The Mountains of Saint Francis: Discovering the Geologic Events That Shaped Our Earth, W.W. Norton and Co, New York, 2008.

Alvarez, W.: The historical record in the Scaglia limestone at Gubbio: magnetic reversals and the Cretaceous-Tertiary mass extinction, Sedimentology, 56, 137-148, 2009.

Anonymous, I.: Fioretti di San Francesco, Il Novellino, Rizzoli, Milano, 1979 (in Italian).

Artz, F. B.: The Mind of the Middle Ages: An Historical Survey University of Chicago Press, Chicago, 2014.

Blatt, S. J.: Continuity and Change in Art: The Development of Modes of Representation, In collaboration with Ethel S. Blatt, Lawrence Erlbaum Associates, Hillsdale, N.J., and London, 1984.

Brogi, A. and Fabbrini, L.: The Monte Penna thrust (southern Tuscany, Italy): Geometry and kinematic of a collisional structure affecting the Tuscan Nappe during the Northern Apennines orogenic building, Ital. J. Geosc., 129, 74-90, 2010.

Cadden, J.: Science and Rhetoric in the Middle Ages: The Natural Philosophy of William of Conches, J His Ideas, University of Pennsylvania Press, 56, 1-24, 1995.

Carrara, C., Ferreli, L., Guerrieri, L., and Serva, L.: The Rieti Intermountain Basin and S. Francesco d'Assisi, IGAG - CNR, Apat Italian Agency for Environmental Protection and Technical Services, Roma, 2004.

Chenu, M.-D.: Nature, Man and Society in the Twelfth Century, Chicago UP, 1983.

Crombie, A. C.: Science, Art and Nature in Medieval and Modern Thought, Rio Grande, Ohio, Hambledon Press, 1996.
Dall'Asta, A.: Nascere Il Natale nell'arte, Editioni San Paolo, Milano, 2012.

Edgerton, S. Y.: The Renaissance Rediscovery of Linear Perspective, New York: Basic Books, 1975.

Edgerton, S. Y.: The Heritage of Giotto's Geometry Art and Science on the Eve of the Scientific Revolution, Cornell University Press, Ithaca, 1993.

Falcetti, S., Guerrieri L., Marino, M., Martarelli, L., Menotti, R.M., Millesimi, F., Moretti, P., and Scalise, A. R.: Field trip guide to the Rieti Plain and the Rieti town. Geological and hydrogeological aspects of a territory featured by historical and cultural heritage, Mem. Descr. Carta Geol. d'It.102, 73-86, Fig. 15 Servizio Geologico d'Italia-ISPRA Roma, 2014.

French, R. and Cunningham, A.: Before Science: The Invention of the Friars' Natural Philosophy, Aldershot Scholar Press, Aldershot, UK, 1996.

Fusarelli, M.: Guide to the Sanctuaries of the Rieti Valley, B. N. Marconi, Rieti, 1999.

Galdenzi, S.: Sasso Pozzo Cave (Gagliole, Italy): Hydrology and Speleogenetic Evolution, Alpine and Mediterranean Quaternary, 26, 65-76, 2013.

Grant, E.: The Foundations of Modern Science in the Middle Ages: Their Religious, Institutional and Intellectual Contexts Cambridge: Cambridge University Press, https://doi.org/10.1017/CBO9780511817908, 1996.

Grant, E.: The Nature of Natural Philosophy in the Late Middle Ages, Studies in Philosophy and the History of Philosophy, 52, Catholic University of America Press, Washington, D.C., 2010.

Guidoboni, E. and Ferrari, G.: The effects of earthquakes in historical cities: the peculiarity of the Italian case, SGA Storia Geofisica Ambiente, Annali di Geofisica, Bologna, Italy, Vol. 43, N. 4, August 2000 .

St. Victor, H.: Patrologia Latina cursus completus, Opera omnia Vol. 175, Migne, J. P., Vivès, Paris, 1854 (in Latin).

Lena, G., Barchi, M. R., Alvarez, W., Felici, F., and Minelli, G.: Mesostructural analysis of S-C fabrics in a shallow shear zone of the Umbria-Marche Apennines (Central Italy), Geol. Soc. London, 409, 149-166, 2014.

Mancini, M. and Cavinato, G.: The Middle Valley of the Tiber River, Central Italy: Plio-Pleistocene Fluvial and Coastal Sedimentation, Extensional Tectonics and Volcanism, Fluvial Sedimentology VII, 373-396, 2009.

Moleta, V.: From St. Francis to Giotto, Franciscan Herald Press, Chicago, 1983.

Nessi, S.: Inventario e regesti d' Archivio del Sacro Convento d'Assisi 90 n. 233 Padua, 1991 (in Italian).

Panofsky, E.: Perspective as Symbolic Form, Zone Books, Princeton, NJ, 1997.

Pizzorusso, A.: Tweeting da Vinci, Da Vinci Press, New York, 2013. Schama, S.: Landscape and Memory, Knopf, New York, 1995. 